\title{
Reproductive and Productive Performance of Up-Country Exotic Dairy Cattle Breeds of Sri Lanka
}

\author{
K.M.P.M.B. Kollalpitiya, S. Premaratne ${ }^{1^{*}}$ and B.L. Peiris ${ }^{2}$ \\ Postgraduate Institute of Agriculture \\ University of Peradeniya \\ Sri Lanka
}

\begin{abstract}
The objective of the study was to assess the production and reproduction performance of up country dairy cattle breeds in Sri Lanka. A total of 200 dairy cows were selected for the study from 4 breeds (Friesian, Ayrshire, Jersey and Crossbred). The traits studied were age at $1^{\text {st }}$ service, age at $1^{\text {st }}$ calving, birth weight, mean milk production per lactation, average milk production per day, post partum heat, and calving interval for 6 lactation periods. It was revealed that the age at $1^{\text {st }}$ service $\left(679\right.$ day) and age at $1^{\text {st }}$ calving (998 days) of Friesian were lower $(p<0.05)$ than those of other breeds. Highest $(P<0.05)$ birth weight of $35 \mathrm{~kg}$ was reported from Friesian compared to other breeds. Mean lowest $(P<0.05)$ post partum heat of 75 day was recorded from Jersey. The lowest $(p<0.05)$ calving interval of 403 days was reported from Jersey compared to other breeds. The highest $(p<0.05)$ milk production per day $(17 \mathrm{~L} /$ day) and per lactation $(5519 \mathrm{~L})$ were recorded from Friesian. Reproductive and productive performances of Friesian and Jersey breeds were better than Ayrshire and Cross-bred cows. Lowest average age at $1^{\text {st }}$ service and age at $1^{\text {st }}$ calving, highest birth weight and milk production were reported from Friesian, whereas, the lowest mean post partum heat and calving interval were recorded from Jersey. Differences in reproductive and productive performances were mainly attributed to breed and different feeding and management systems used in different farms.
\end{abstract}

Keywords: Temperate breeds, reproduction, production, up-country

\section{INTRODUCTION}

Many factors influence the distribution of cattle farming in Sri Lanka such as, the agroecological zones, proximity to markets and feed resources. Milk production systems vary between and within agro-ecological zones. Based on the rainfall pattern and altitude, the country is divided into three main agro-ecological zones namely, low country, mid country and the up-country and, the low and mid country regions again being divided into wet zone, intermediate zone and a dry zone. The wet mid- and up-country areas are often perceived as the main dairy producing areas of Sri Lanka (Census of Agriculture, 2002). Mainly Intensive system of cattle farming is practiced in up-country, with permanent housing and feeding with concentrates (Bandara et al., 2011). Up-country region receives $>2000 \mathrm{~mm}$ mean annual rainfall and temperature ranges from $10^{\circ} \mathrm{C}$ to $32^{\circ} \mathrm{C}$ which is a suitable climatic and topographical environment for European breeds (Ibrahim et al., 1999). The government and private sectors have large cattle farms of European breeds, primarily the Ayrshire, Jersey and Friesian in the up-country areas that have a high dairy potential.

Department of Animal Science, Faculty of Agriculture, University of Peradeniya, Peradeniya, Sri Lanka

Department of Crop Science, Faculty of Agriculture, University of Peradeniya, Peradeniya, Sri Lanka

Author for correspondence: sujaprema@gmail.com 
Although several livestock development activities, such as introduction of exotic genotypes, artificial insemination, herd improvement programs, embryo transfer, and heifer calf rearing programs etc. had been carried out in order to improve fertility in cows, the efforts to assess the productive and reproductive performance of cows are scarce. Sri Lanka is currently about $15-20 \%$ self-sufficiency in milk that has been mostly achieved with the use of imported milk powder (Central Bank, 2010). The import bill on dairy commodities is around 15 billion rupees or approximately 13 million USD (Central Bank, 2009). The Government, at the same time, has an ambitious target for growth in dairy production, to increase towards $50 \%$ self sufficient target in milk products by 2015 (Livestock Development Report, 2010). At the current growth rate of $1-2 \%$ per annum, the sector will need to grow at about $15 \%$ annually for the next few years with no increase in total consumption (Livestock Development Report, 2010) to achieve the about target.

A wide scope still exists for profitable high milk producing and income generating dairy farming in the up-country area. Reproduction is an important consideration in the economics of cattle production. Nevertheless, economics of cattle production depends largely on the feeding and management of cattle. In order to obtain the maximum milk production from cow, maximum numbers of lactations have to be obtained with her economic life span. A calf birth is essential before successful lactation begins. Therefore, fertility and milk production are highly interrelated. To obtain more calves, calving interval (CI) should be as shortest as possible. In the absence of regular breeding and calving at the appropriate time, cattle rearing will not be profitable. Prolonged calving intervals decrease production per cow when measured by day of life. Infertility results in few calves born per cow per year and increased incidences of culling. After first calving, good reproduction is characterized by a sequence of successive normal calving with viable calves. A healthy calf each year is the usual goal. This is possible only by increasing the reproductive efficiency of animals.

Age at $1^{\text {st }}$ service (AFS), age at $1^{\text {st }}$ calving (AFC), birth weight (BW), total milk yield (TMY), average milk yield per day (AMYD), calving to $1^{\text {st }}$ service interval (CSI) and calving interval $(\mathrm{CI})$ are the important parameters that determine cattle reproductive and productive efficiency and these are important factors in terms of economics of dairy management (Dematawawa \& Beger, 1998). Therefore, the objectives of the present investigation were to evaluate the reproductive and productive performance of exotic dairy cattle breeds in large scale intensive farms in up-country of Sri Lanka.

\section{MATERIALS AND METHODS}

\section{Location of the study}

Data were collected from four farms located in up-country, Sri Lanka. The area is $2000 \mathrm{~m}$ above the mean sea level, with an annual rainfall of 2000-2500 $\mathrm{mm}$ distributed throughout the year. The mean temperature of the area ranges from $10^{\circ} \mathrm{C}$ in December to $25^{\circ} \mathrm{C}$ in April with Relative Humidity of $75-80 \%$.

\section{Data collection}

Cow service records, birth register, individual cow record cards and other records from 1999 to 2010, were used to obtain data pertaining to each cow reproduction and production parameters of three pure breeds (Friesian, Ayrshire and Jersey) and their crossbreds. In addition, other relevant data such as management practices were also obtained by 
interviewing the farm staff. Fifty animals were selected randomly from each breed so that 200 animal records were used in the study (50 animals x 4 breeds). AFS, AFC, BW, TMPL, AMPD, CSI, and CI of cattle in above farms were recorded. Breeds were confirmed by using the phenotypic characters.

\section{Analysis of data}

The data were analyzed using Microsoft Excel, SAS and MINITAB software packages. The breed effects were analyzed by General Linear Model procedure. Breeds and parity means were compared by Least Significant Difference.

\section{RESULTS AND DISCUSSION}

\section{Reproductive performance}

Effect of breed on reproductive performance of different breeds of cattle is shown in Table 1. The lowest $(\mathrm{P}<0.05)$ average AFS was recorded in Friesian and the highest AFS was recorded in Jersey breed (Table 1). It has been shown in previous studies that well-nourished temperate heifer has the potential to reach the specific weight (2/3 body weight) at 10-12 months, and conceived at 14-15 months of age (Hafez \& Hafez, 2000; Ibrahim \& Zemmelink, 2000). However, different breeds of cattle studied in this experiment have not reached to this standard level of AFS. The reason for this may be the reduced growth rate and delayed puberty due to low level of nutrient intake by heifers in the farms in up-country, Sri Lanka. From weaning to puberty, the amount of concentrate fed to Friesian, Ayrshire, crossbred and Jersey were 5, 3, 2 and $1 \mathrm{~kg} /$ animal/day, respectively. Fresh forage fed to Friesian, Ayrshire, crossbred and Jersey was 40, 35, 30, and $25 \mathrm{~kg} /$ animal/day, respectively. According to several workers (Hafez \& Hafez, 2000), high plan of nutrition could hasten puberty by increasing the growth rate of heifers. In addition, early breeding of heifers would increase the number of calves born and the amount of milk produced during the productive life of the cow. Therefore, feeding and management of Friesian, Ayrshire, crossbred and Jersey heifers must be improved to achieve low AFS and the best future productions.

Table 1. Effect of breed on reproductive performance of cattle (average of 50 cows)

\begin{tabular}{lccc}
\hline Breed & $\begin{array}{c}\text { AFS (days)* } \\
\text { (Mean } \pm \text { SD) }\end{array}$ & $\begin{array}{c}\text { AFC (days)* } \\
\text { (Mean } \pm \text { SD) }\end{array}$ & $\begin{array}{c}\text { BW (kg)* } \\
\text { (Mean } \pm \text { SD) }\end{array}$ \\
\hline Jersey & $769 \pm 180^{\mathrm{a}}$ & $1098 \pm 203^{\mathrm{a}}$ & $21 \pm 2^{\mathrm{c}}$ \\
Crossbred & $754 \pm 203^{\mathrm{ab}}$ & $1058 \pm 224^{\mathrm{ab}}$ & $32 \pm 4^{\mathrm{b}}$ \\
Ayrshire & $699 \pm 127^{\mathrm{bc}}$ & $1010 \pm 135^{\mathrm{b}}$ & $33 \pm 3^{\mathrm{b}}$ \\
Friesian & $679 \pm 134^{\mathrm{c}}$ & $998 \pm 145^{\mathrm{b}}$ & $35 \pm 3^{\mathrm{a}}$ \\
SEM \pm & 23.25 & 25.55 & 0.44 \\
\hline
\end{tabular}

*Age at $1^{\text {st }}$ service, age at $1^{\text {st }}$ calving, birth weight

$a, b, c$ Different superscripts in a column are significantly different at $\mathrm{p}<0.05$

The Friesian cows were significantly $(\mathrm{P}<0.05)$ younger than the cows of crossbred and Jersey at first calving (Table 1). The lowest $(\mathrm{P}<0.05)$ average AFC was recorded from Friesian and the highest AFC from Jersey. However, Chandrasiri et al. (2007) reported that AFC of Friesian and Jersey cattle from the large scale up-country farms (from 1996 to 2003) was 1291 days and 1141 days respectively. 
According to Hafez (1993) and Ibrahim \& Zemmelink (2000), the average AFC for cattle on recommended level of nutrition is 24 to 25 months. Furthermore, Meyer et al. (2005) reported that the standard AFC for temperate dairy breeds is approximately 24 months in their native conditions. According to the results of the present study, AFC values of different breeds of cattle were far below the standard values reported in temperate countries and this may be related with the prevailing climatic conditions and management practices under tropical conditions.

Highest BW of $35 \mathrm{~kg}$ was reported in the Friesian breed, which was significantly $(\mathrm{P}<0.05)$ higher than those of Ayrshire, Jersey and crossbred animals (Table 1). BW of Jersey was less $(\mathrm{P}<0.05)$ compared to all other breeds and the reported value of Friesian was $40 \%$ higher than that of Jersey. According to Ibrahim \& Zemmelink (2000), BW of Friesian, Ayrshire and Jersey breeds in up-country of Sri Lanka were 35, 32 and $25 \mathrm{~kg}$, respectively. Results of the present study are in agreement with the results of Ibrahim \& Zemmelink (2000). Bundy \& Christenson (1984) reported that BW of Friesian calves in the United States were around $40.8 \mathrm{~kg}$. According to the presents study, BW of all breeds was below the BW reported for temperate countries. The lower BW for all breeds in Sri Lanka may be related with the climate and management conditions prevailed in Sri Lanka as a tropical country.

The breed had a significant effect $(\mathrm{P}<0.05)$ on the mean CSI of cows (Table 2). Lowest mean CSI of cows was observed in Jersey followed by Ayrshire, Friesian and Crossbred. Abegunawardana et al. (1998) reported that CSI of cows of up-country multiple cattle farms was 111.2 day and calving to conception interval was 156.92 day. CSI values reported in the present study are much lower than the previous values reported from Sri Lanka but higher than the values reported from temperate countries. This difference in CSI of dairy cows in up-country Sri Lanka may be related with the climate, feeding and management of cows in these farms. According to Abegunawardana (2002), resumption of ovarian activity can be influenced by age of cow, pre- and post-partum nutrition, pre- and post-partum disease, lactation and suckling.

The time taken for post partum heat (PPH) can be influenced by a number of factors such as parity status of the cow, abnormal parturition like dystocia and retained placenta, mild uterine infections, pyometra, the degree of contamination of the genital tract and the level of milk production. Suckling and the plane of nutrition also delay the time of the first ovulation in cows (Hafez \& Hafez, 2000). Effect of breed on CI of cows is shown in Table 3.

Table 2. Effect of breed on Calving to $1^{\text {st }}$ Service Interval of cattle (average of 50 cows)

\begin{tabular}{|c|c|c|c|c|c|c|c|}
\hline \multirow[t]{3}{*}{ Breed } & \multicolumn{7}{|c|}{ Calving to $1^{\text {st }}$ service interval (days) } \\
\hline & $1^{\#}$ & $2^{\#}$ & $3^{\#}$ & $4^{\#}$ & $5^{\#}$ & $6^{\#}$ & Mean $_{\#, \#}$ \\
\hline & $\begin{array}{c}\text { (Mean } \pm \\
\text { SD) }\end{array}$ & $\begin{array}{c}\text { (Mean } \pm \\
\text { SD) }\end{array}$ & $\begin{array}{c}\text { (Mean } \pm \\
\text { SD) }\end{array}$ & $\begin{array}{l}\text { (Mean } \pm \\
\text { SD) }\end{array}$ & $\begin{array}{c}\text { (Mean } \pm \\
\text { SD) }\end{array}$ & $\begin{array}{l}\text { (Mean } \pm \\
\text { SD) }\end{array}$ & $\begin{array}{c}\text { (Mean } \pm \\
\text { SD) }\end{array}$ \\
\hline Jersey & $83 \pm 28^{b}$ & $75 \pm 23^{b}$ & $59 \pm 15^{\mathrm{c}}$ & $76 \pm 19^{\mathrm{ab}}$ & $82 \pm 17^{b}$ & $75 \pm 20^{b}$ & $75 \pm 20^{b}$ \\
\hline bred & $87 \pm 18^{\mathrm{b}}$ & $79 \pm 20^{\mathrm{b}}$ & $87 \pm 30^{\mathrm{a}}$ & $76 \pm 25^{\mathrm{ab}}$ & $96 \pm 20^{\mathrm{a}}$ & $83 \pm 23^{\mathrm{a}}$ & $85 \pm 30^{\mathrm{a}}$ \\
\hline & $89 \pm 30^{\mathrm{b}}$ & $84 \pm 23^{\mathrm{ab}}$ & $73 \pm 21^{\mathrm{b}}$ & $69 \pm 23^{b}$ & $67 \pm 24^{c}$ & $79 \pm 23^{\mathrm{ab}}$ & $77 \pm 24^{b}$ \\
\hline & $104 \pm 57^{\mathrm{a}}$ & $93 \pm 33^{\mathrm{a}}$ & $82 \pm 28^{\mathrm{ab}}$ & $80 \pm 23^{\mathrm{a}}$ & $72 \pm 21^{\mathrm{c}}$ & $75 \pm 20^{\mathrm{b}}$ & $84 \pm 23^{\mathrm{a}}$ \\
\hline $\mathrm{SEM} \pm$ & 5.17 & 3.55 & 3.47 & 3.20 & 2.90 & 3.03 & 3.55 \\
\hline
\end{tabular}

\# Average of 50 cows; 1-6 indicate animals of 6 heats

\#,\# Average of 300 (50 cows x 6 heats)

${ }^{a, b, c}$ Different superscripts in a column are significantly different at $\mathrm{p}<0.05$ 
The breed had a significant $(\mathrm{P}<0.05)$ effect on $\mathrm{CI}$ and the mean lowest $\mathrm{CI}$ was recorded in Jersey compared to other breeds (Table 3). According to Roberts (1986), CI of a well managed dairy herd should be between 12-13 months whereas De Silva and Sathasivampillai (1975) reported a value of 16-17 months for cows in up-country, Sri Lanka, irrespective of the breed. The national level of CI of cows in Sri Lanka has been reported to be 464 day by Herath \& Balachandran (1993). The values of CI reported for Friesian and Ayrshire breeds in up-country, Sri Lanka in this study is in accordance with the findings reported by Herath et al. (2002). These results were also in accordance with Ruvuna et al. (1983), who reported longer days open for Friesian than for Jerseys. Badinga et al. (1985) compared Friesian and Jersey breeds and found higher conception rates and fewer services per conception for Jerseys. Long CIs indicate the low fertility and the optimum level of fertility has been indicated by a Calving Index (mean CI of a herd) of 365 days.

Table 3. Effect of breed on calving interval

\begin{tabular}{|c|c|c|c|c|c|c|}
\hline \multirow[t]{2}{*}{ Breed } & \multicolumn{6}{|c|}{ Calving interval (days) } \\
\hline & $\begin{array}{c}1^{\#} \\
\text { (Mean } \pm \\
\text { SD) }\end{array}$ & $\begin{array}{c}2^{\#} \\
\text { (Mean } \pm \\
\text { SD) }\end{array}$ & $\begin{array}{c}3^{\#} \\
\text { (Mean } \pm \\
\text { SD) }\end{array}$ & $\begin{array}{c}4^{\#} \\
\text { (Mean } \pm \\
\text { SD) }\end{array}$ & $\begin{array}{c}5^{\#} \\
\text { (Mean } \pm \\
\text { SD) }\end{array}$ & $\begin{array}{l}\text { Mean }^{\#, \#} \\
\text { (Mean } \pm \\
\text { SD) }\end{array}$ \\
\hline Jersey & $418 \pm 83^{\mathrm{a}}$ & $412 \pm 68^{\mathrm{a}}$ & $384 \pm 36^{\mathrm{c}}$ & $393 \pm 33^{b}$ & $409 \pm 47^{\mathrm{a}}$ & $403 \pm 24^{c}$ \\
\hline & $443 \pm 84^{\mathrm{a}}$ & $411 \pm 85^{\mathrm{a}}$ & $447 \pm 115^{\mathrm{a}}$ & $424 \pm 82^{\mathrm{a}}$ & $415 \pm 59^{\mathrm{a}}$ & $428 \pm 85^{\mathrm{a}}$ \\
\hline & $420 \pm 68^{\mathrm{a}}$ & $407 \pm 70^{\mathrm{a}}$ & $386 \pm 50^{\mathrm{bc}}$ & $413 \pm 76^{\mathrm{ab}}$ & $414 \pm 73^{\mathrm{a}}$ & $408 \pm 29^{\mathrm{bc}}$ \\
\hline & $451 \pm 120^{\mathrm{a}}$ & $415 \pm 93^{\mathrm{a}}$ & $420 \pm 114^{\mathrm{ab}}$ & $412 \pm 66^{\mathrm{ab}}$ & $418 \pm 104^{\mathrm{a}}$ & $423 \pm 99^{\mathrm{ab}}$ \\
\hline $\mathrm{SEM} \pm$ & 12.85 & 11.17 & 12.23 & 9.51 & 10.42 & 11.25 \\
\hline
\end{tabular}

\#Average of 50 cows; $1-5$ indicate animals with 5 calving intervals

\# Mean of 250 ( 50 cows x 5 calving intervals)

${ }^{\mathrm{a}, \mathrm{b}, \mathrm{c}}$ Different superscripts in a column are significantly different at $\mathrm{P}<0.05$

\section{Productive performance}

Breed had a significant effect $(\mathrm{P}<0.05)$ on AMYD of cattle breeds (Fig. 1). AMYD of Friesian breed was $17 \mathrm{~L}$ and it was significantly $(\mathrm{P}<0.05)$ higher than that of other breeds. AMYD of Ayrshire was $14 \mathrm{~L}$ and the lowest AMYD of $7 \mathrm{~L}$ was recorded in Jersey breed (Fig.1). According to Jayathilake et al. (2003), AMYD for Ayrshire was $7.5 \mathrm{~L}$ per day in upcountry, Sri Lanka whereas a value of $14 \mathrm{~L} /$ day was recorded in the present study. Ranaweera (2007) reported that overall average milk yield/day of up-country cows was 6-8 L. Longer lactation length reduced the AMYD of cattle and also increased the CI. Therefore, cow must be dry off 40-60 days prior to the expected date of calving. As a "rule of thumb" provision of recommended amount of roughage and concentrate can improve the milk production of cattle (Abegunawardana et al., 1997). In the present study, pregnant cows of Friesian, Ayrshire, crossbred and Jersey were fed with 8, 6, 4 and $2.5 \mathrm{~kg}$ concentrate (mixture of coconut poonac and rice bran)/animal/day respectively. Amount of forage fed to Friesian, Ayrshire, crossbred and Jersey were 50, 45, 45, and $40 \mathrm{~kg} /$ animal/day, respectively. Friesian and Ayrshire were fed with a mixture of rye grass (Lolium perenne) and tall fescue (Festuca arunudiceae) whereas crossbred and Jersey were fed with kikiyu (Penisetum clandestinum), napier (Penisetum purpureum) and natural grasses. On the other hand, lactating cows of Friesian, Ayrshire, crossbred and Jersey were fed with 11, 8, 6 and $4 \mathrm{~kg}$ of concentrate per animal per day, respectively. Amount of forage fed to lactating Friesian, Ayrshire, crossbred and Jersey were 50, 45, 45, and $45 \mathrm{~kg} /$ animal/day, respectively. 


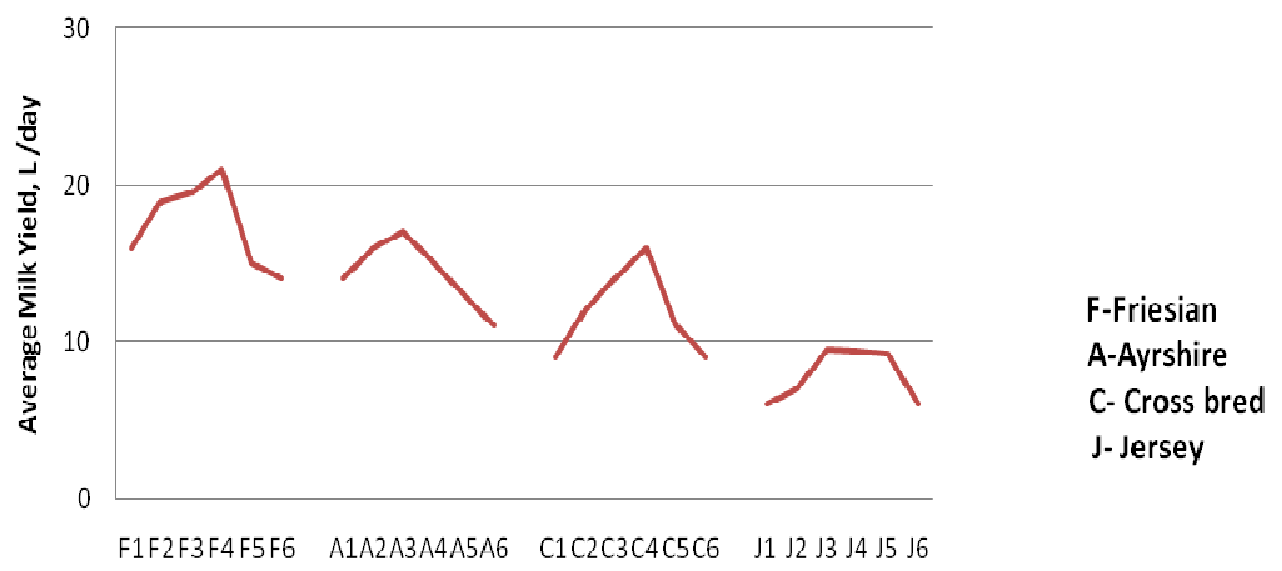

Fig. 1. Average milk yield per day (average of 50 cows) of dairy cattle breeds

$1,2,3,4,5,6=$ number of lactations

Effect of breed on milk yield per lactation is shown in Fig. 2. The highest $(\mathrm{P}<0.05)$ TMY per lactation of $5519 \mathrm{~L}$ was reported in the Friesian breed whereas the lowest TMY per lactation was recorded from Jersey (2316 L). According to livestock data of Department of Animal Production and Health, in 1997, the average milk yield of up-country cattle was $8 \mathrm{~L} / \mathrm{cow} /$ day or about $2500 \mathrm{~L} / \mathrm{cow} /$ lactation. Buvanendran (1974) reported a value of $1956 \mathrm{~kg}$ for 305 days of lactation for Ayrshire breed in up-country of Sri Lanka. But Friesian and Ayrshire cows bred in Ithaca in United States produced milk yield of $6577 \mathrm{~kg}$ and $5343 \mathrm{~kg}$ /lactation, respectively (Norman et al., 2009).

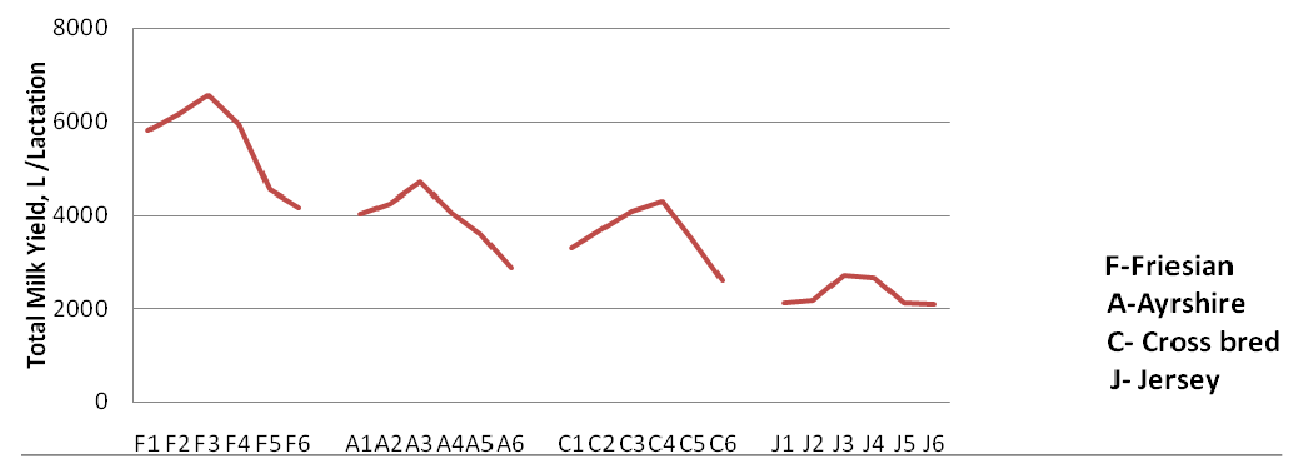

Fig. 2. Total milk production (average of 50 cows) of dairy cattle per lactation

$1,2,3,4,5,6=$ number of lactations

\section{CONCLUSIONS}

The reproductive and productive performance of Friesian and Jersey cows were better than those of Ayrshire and crossbred cows. The lowest average AFS, AFC, highest BW, TMYL and AMYD were reported from the Friesian, whereas the lowest mean CSI and CI were recorded in Jersey breed. The poor reproductive and productive performances of the exotic 
breeds in up-country could mainly be attributed to climatic conditions and feeding and management practices of these animals. It is possible to improve the reproductive and productive performance of dairy cows by better management practices, improved nutrition and use of new reproductive technology.

\section{ACKNOWLEDGEMENTS}

The authors wish to express their sincere thanks to Director, Postgraduate Institute of Agriculture, University of Peradeniya and, Manager and Staff of Ambewela, Bopathalawa, Dayagama and New Zealand Farms.

\section{REFERENCES}

Abegunawardana, H. (2002). Reproduction and Obstetrics in the Farm Animals ( $2^{\text {nd }}$ edition). University of Perdeniya, Sri Lanka. NARESA Press, Colombo, Sri Lanka. 1, 1-13.

Abegunawardana. H., Ratnayake, D. and Jayathilake, M.W.A.P. (1997). Characteristics of cattle farming systems in Sri Lanka. J. Natn, Sci, Coun. 25(1), 25-38.

Abeygunawardena, H., Alexandra, P.A.B.D, and Abeygunawardena, I.S. (1998).

Reproductive performance and factors affecting the success of artificial insemination in of cattle in up-country multiplier farms in Sri Lanka. Trop. Agric. Res. 10, 356-371.

Badinga, L., Collier, R.J. Thatcher, W.W. and Wilcox, C.J. (1985). Effects of climatic and management factors on conception rate of Dairy cattle in subtropical environment. Dairy Sci. $68,78-85$.

Bandara, D.M.D.S., Premaratne, S. and Dematawewa, C.M.B. (2011). Production and Economic Characteristics of Intensive and Semi- Intensive Dairy Cattle Management Systems in Vegetable Based Farming System in Welimada, Sri Lanka. Trop. Agric. Res. 22(3), 314-323.

Bundy, C.E. and Christenson, V.W. (1984) Dairy Production (5th ed). Englewood Cliffs, New Jersey, Prentice-Hall, Inc.

Buvanendran, V. (1974) Crossbreeding experiments of Jersey with Indian zebu breeds. Brief Communication. Vol. JE. XIX International Dairy Congress, India. 19, 50-55.

Census of Agriculture (2002). Agriculture and Environmental Statistics Division, Department of Census and Statistics, Colombo, Sri Lanka.

Central Bank Report (2009) and (2010). Central Bank of Sri Lanka. Colombo, Sri Lanka.

Chandrasiri, A.D.N., Gamage, D.V.S., Weerasinghe, W.M.S.P., Malkanthi, R.M.S and Fernando, W.P.D.K. (2007). Age at first calving of two temperate breeds of cattle in large scale upcountry farms, Sri Lanka Vet. J. 54 and 55(A), 1-6.

Dematawewa, C.M.B. and Beger, P.J. (1998). Genetic and phenotypic parameters for 305day Yield, Fertility, and Survival in Holsteins. J. Dairy Sci. 81, 2700-2709. 
De Silva, G.A.C and Sathasivampillai, K. (1975). Survey on artificial inseminations and associated management practices of neat cattle in mid country and Jaffna peninsula of Sri Lanka. Division of Agricultural Economics, Farm Management and Statistics, Dept. of Agriculture. pp.56.

Hafez, E.S.E. (1993). Reproduction in Farm Animals (Sixth Edition). Lea and Febiger, Philadelphia.

Hafez, E.S.E. and Hafez, B. (2000). Reproduction in Farm Animals ( $7^{\text {th }}$ edition). Lea and Febiger, Philadelphia, USA.

Herath, H.M.S.P. and Balachandran, K. (1993) Fertility in small holder cattle herds in Sri Lanka. Sri Lanka Vet J. 40(1), 29-30.

Hearth, H.M.S.P., Sivayoganathan, B, and Dissanayake, S. (2002) A Retrospective studies on Reproductive performance of cows in Agro-ecological zones of central province of Sri Lanka. Sri Lanka Vet J. 49(2A), 1-6.

Ibrahim, M.N.M., Staal, S.J., Daniel, S.L.A. and Thorpe, W. (1999). Appraisal of the Sri Lanka dairy sector, Volume 1. Synthesis report. Department of Animal Science, University of Peradeniya; International Livestock Research Institute, Nairobi, Kenya and Ministry of Livestock Development and Estate Infrastructure, Colombo, Sri Lanka. pp 7.

Ibrahim M.N.M and Zemmelink, G. (2000). A comparative evaluation of integrated farm models with the village situation in the Forest-Garden area of Kandy, Sri Lanka. Asian-Aus. J. Anim. Sci. 13(1), 53-59.

Jayathilake, P.S., Silva, G.L.L.P. and Dematawawa, C.M.B. (2003) Preference for Ayrshire breed among up country smallholder farms. Sri Lanka Vet. J. 50(1), 34-40.

Livestock Development Report (2010). Department of Animal Production and Health, Gatambe, Peradeniya.

Meyer, M.J., Everett, R.W. and Van Amburgh, M.E. (2005) Reduced age at $1^{\text {st }}$ calving: effects on life time production, longevity, and profitability. Arizona and New Mexico Dairy Newsletter Cooperative Extension, Department of Animal Science, Cornell University. Ithaca, NY. pp 20-45.

Norman, H.D., Hutchison, J.L. and Wright, J.R. (2009) Reproductive Status of Holstein and Jersey cows in the United States J. Dairy Sci. 92, 3517-3528.

Ranaweera, N.F.C (2007) Improved Market Access and Smallholder Dairy Farmer Participation for Sustainable Dairy Development. Lessons Learned Sri Lanka. FAO Report. pp 5-21.

Roberts, S.J. (1986). Veterinary Obstetrics and Genital Diseases. Theriogenology ed 3. North Pomfret, VT 05053, Woodstock, Vermont, USA: David and Charles Inc.

Ruvuna, F., McDaniel, B.T., McDowell, R.E., Johnson, Jr., J.C., Hollon, B.T. and Brandt, G.W.(1983) Crossbred and purebred dairy cattle in warm and cool seasons. J. Dairy Sci. 66, 2408-2417. 